\title{
Biosciences lose out to defence
}

\section{Washington}

A HUGE increase in defence spending, including defence research and development, dominates President Reagan's proposed budget for fiscal year 1987. Total federal obligations for research and development, including facilities, are estimated at $\$ 63,000$ million, 16 per cent above the 1986 level of $\$ 54,000$ million. Military programmes in the Departments of Defense and Energy, as in previous years, account for most of the increase. But substantial increases are also proposed for the National Science Foundation (NSF) and the National Aeronautics and Space Administration (NASA). The physical sciences in general have been relatively well treated. Biomedical research is a different story.

The budget continues all the wellknown Reagan themes. Budget authority for the Strategic Defense Initiative (SDI) will increase from $\$ 2,800$ million in 1986 to $\$ 4,800$ million in 1987 , Congress permitting. Research and development by the Department of Defense would increase to 60 per cent above its 1984 level; only $\$ 21,000$ million of the $\$ 63,000$ million budget for federal research and development would be non-defence, $\$ 7,600$ million of that for non-military basic research. Pet Reagan hates such as the Sea Grant programme of the National Oceanic and Atmospheric Administration and the computer sciences and technology and fire and building research programmes at the National Bureau of Standards are scheduled (as they have been before) to be killed. The Environmental Protection Agency takes a 7 per cent cut.

Tension between the administration and Congress over the budget is unusually high this year, because of last year's controversial legislation setting fixed targets for reducing the federal budget deficit in each of the next five years. Under the Gramm-Rudman deficit reduction act, automatic across-the-board cuts will come into effect if Congress fails to pass budgets meeting the target.

The new 1987 budget proposal foresees total spending of $\$ 944,000$ million, with a deficit of $\$ 143,600$ million, just under the limit specified by Gramm-Rudman. But the administration's refusal to consider tax increases, together with a 12 per cent increase in total military spending, has meant hefty cuts to many domestic programmes, which Congress is unlikely to approve. Instead, the appropriate committees and Congress as a whole can be expected to make several changes, with the result that the actual budget for the financial year beginning on 1 October 1986 will probably look even less like the President's proposal than usual, if
Gramm-Rudman stands. But further uncertainty was introduced last week when a federal judicial panel unanimously ruled the automatic cuts provision of GrammRudman unconstitutional; the question will now go to the Supreme Court, which is not expected to rule before the summer.

Meanwhile, the administration's proposals are as follows.

\section{National Science Foundation}

The foundation's budget request is $\$ 1,685.7$ million, an increase of 8.4 per cent. Even so, the mood at NSF is temperate. Director Erich Bloch points out that in 1983 constant dollars, the 1987 request represents a negligible increase over the 1985 amount (after a decrease in 1986). The foundation says that even if Congress should approve the full request, that would be only just good enough, in part because of the increasing complexity - and cost - of research equipment. But in the Gramm-Rudman era's scramble for funds, full approval seems unlikely.

NSF lists for "special emphases" for 1987: biotechnology, computational science and engineering, global geosciences and broadening participation in research and education. If NSF sustains budget cuts during the impending legislative fray, the foundation would probably seek to protect them

NSF is planning to establish between two and four new multidisciplinary biotechnology research centres, as well as an undefined number of so-called minicentres. A 50 per cent increase to $\$ 84$ million is wanted for computational science and engineering; the global geosciences effort would jump from $\$ 17$ million to $\$ 35$ million, and would include the development of Earth-based and satellite observational instrumentation, a project for which the administration has a special enthusiasm.

NSF's plans to expand participation in science and engineering research and education include $\$ 4$ million for the new Minority Research Centers of Excellence programme and a $\$ 13$ million increase

US research and development budget (\$ million)

\begin{tabular}{lccc} 
& 1985 & 1986 & 1987 \\
Defence-related & actual & estimated & $\begin{array}{c}\text { proposed } \\
\text { Health and Human Services }\end{array}$ \\
(NIH) & 31,099 & 33,485 & 41,823 \\
Energy & 5,444 & 5,524 & 5,471 \\
NASA & $(4,824)$ & $(4,905)$ & $(4,672)$ \\
NSF & 4,901 & 4,785 & 4,886 \\
Agriculture & 3,235 & 3,594 & 4,051 \\
EPA & 1,346 & 1,334 & 1,508 \\
R\&D facilities & 941 & 922 & 907 \\
All other & 320 & 334 & 310 \\
Total & 1,894 & 1,812 & 1,734 \\
& 2,205 & 2,048 & 1,847 \\
\hline
\end{tabular}

\section{Due process of law}

IN anticipation of legal challenges to the constitutionality of Gramm-Rudman, the bill itself contains specific procedures to be followed. Rather than proceed from district court to appeals court to Supreme Court, any challenge goes first to a special panel of federal judges who issue a ruling. If there is an appeal against the panel's ruling, the case goes immediately to the Supreme Court.

In fact, challenges did arise. Several congressmen joined a suit brought by the National Treasury Employees Union. On 7 February, the panel issued its ruling declaring the automatic-cuts provision of Gramm-Rudman unconstitutional.

Now it falls to the heavily burdened Supreme Court to make a final determination. That decision is unlikely to come before July. Until then, federal agencies will have to live in fear of next fall's Gramm-Rudman axe.

over the $\$ 50$ million spent in 1986 to improve undergraduate research.

Two more of the agency's pet projects are seeking increased support. NSF's supercomputer centres stand to gain almost 19 per cent over their current $\$ 45.2$ million, but the total, $\$ 53.6$ million, will be spent on bringing on stream the five centres now being set up. NSF has chosen to push networking and software research rather than to establish new centres in 1987, even though the National Science Board's initial mandate called for 10 facilities.

The nascent engineering research centre network grabbed a $\$ 12$ million increase over this year's budget of $\$ 23$ million. Six centres have been established so far, and NSF hopes to have 15 by the end of 1987 .

National Institutes of Health

The proposed total budget for the National Institutes of Health (NIH) is $\$ 4,936$ million, a substantial drop from the $\$ 5,353$ million comparable figure appropriated by Congress for 1986 . This repeats a now familiar pattern: the administration proposes cuts for NIH, only to have Congress reverse them and vote huge increases a few months later. But this year, because of 